\title{
Electrochemical Medicinal Analysis of Bhumi Amla
}

\author{
Jeetnarayan Chaturvedi $^{1 *}$, M.U. Khan ${ }^{1}$, Shailja Sachan ${ }^{2}$, Arvind Prasad Dwivedi ${ }^{3}$ \\ ${ }^{1}$ Department of Chemistry, A.P.S. University Rewa (M.P.) India \\ ${ }^{2}$ Head of Department of Chemistry Govt. M. S. Golvalkar College Rewa (M.P.) India \\ ${ }^{3}$ Department of chemistry, Govt. Sanjay Gandhi Smrati Auto., P.G., College Sidhi M.P
}

*Corresponding Author: Jeetnarayan chaturvedi, Department of Chemistry, A.P.S. University Rewa (M.P.) India

\begin{abstract}
The phytochemical analysis of three varieties of medicinal plants of Bhumi Amla (BA) eubhorbiaceae family and their medicinal role is recognized and well documented. The main constituents such as chlorophylls, carotenoides, amino acids, lignin etc have been estimated. The spectral analysis of the electrolytes was carried out for Serum Glutamic Pyruvic Transaminase (SGPT) test. The analysis of system was fluorometrically reported and numerous physical parameters have been determined. The relative mobility of the medicinal plants was measured by electrophoretic method. The observed activity in conformity with the experimental results have been discussed.
\end{abstract}

Keywords: Photosynthesis, enzyme, Florescent, Bio-fluid, Electrophoresis.

\section{INTRODUCTION}

The recent advancements in medicinal chemistry not only revolutionized in traditional practice in allopathic system but in Ayurvedic generic life medicines too. The purified chemical derivatives of herbs like extracts, fractionates, and isolates are being preferred which are medicinally better than other synthetic drugs. During the last few decades, the advance studies of natural products has been tremendously was a field of research in chemistry, material science as well as life science. Natural products have come from various source material including terrestrial plants, from plant kingdom.

Our country is a paradise for medicinal plants. There exist a large number of plants which have been used by Ayurveda and Unani practitioners as medicines since long ago. A large number of herbal and aromatic plants were used in India, as the presence of human beings has to depend on nature for their survival and the accumulated knowledge has guided them to discover remedies for the diseases. In the recent era a little attention was paid to the development of the Indigenous drugs, which was revised in India. The wealth of India was published by $\operatorname{CSIR}^{1,2}$ envisaging the Bhumi Amla and its extracted constituents, which yield the drugs usually used as a clinical trial, cultivation and economical importance.

Systematic phytochemical analysis of drugs used in indigenous medicine was taken-up on modern scientific lines. A large number of compouds ${ }^{3}$ of different functional groups are found in different varieties of Bhumi Amla. Inspired from above and available literature pertaining to the electrochemical medicinal analysis for three species of Bhumi Amla which has not so far been reported in detail till date by a couple of earlier workers ${ }^{4-10}$. The authors thought it worth-while to report the analysis of medicinal plants (BA) for their important constituents.

\section{EXPERIMENTAL (MATERIALS AND METHODS)}

The $20 \mathrm{gm}$ of leaves of Bhumi Amla medicinal plants are plucked, macerated, washed with distilled water and crushed to extract electrolytes of three species of the sample purified by distillation to get sap. The processed leaf is studied under the microscope to check the different layers of the epidermal cells. The filtrate is extracted with ether or chloroform to remove water soluble non-basic organic materials and then steam redistilled. The medicinal chemical analysis of bio-mass for chlorophylls, free amino acids, active ingredients (phyllanthin and hypophyllanthin), relative mobilities and other physical parameters alongwith the constituents of system have been carried out conventionally by 
standard ascending paper chromatographic method followed by measurement of their $\mathrm{R}_{\mathrm{f}}$ values. The other sophisticated methods such as UV, fluorescent spectroscopy and electrophoretic have been employed to perform the analysis. The moisture content, loss on drying of the sample was also determined.

\section{RESULTS AND DISCUSSION}

\subsection{Chemical Analysis of Chlorophylls}

Biologically chlorophyll-a and chlorophyll-b are very important natural pigments responsible for the synthesis of all kinds of foods, their chemical analysis alongwith xanthophylls and carotenes for the systems was chromatographically analyzed by measuring their $\mathrm{R}_{\mathrm{f}}$ values as recorded in Table- 1 . Chlorophylls ultimately in presence of sunlight build carbohydrates as an end-product of metabolism. The $\mathrm{R}_{\mathrm{f}}$ values of BA-3 is higher than BA- 2 and BA- 1 due to chloroplast, a complex of chlorophyll shows electron flow and formation of ATP due to photonic excitation but bio-electrode potential ${ }^{11}$ (BEP) of BA-1 is higher than BA-2 and BA-3 respectively.

\subsection{Analysis of Amino Acids}

The bacterial free extract of soluble fractions in $80 \%$ ethanol is taken for the separation and identification of free amino acids by ascending paper chromatographic methods. The extract is treated with a drop of toluene as preservative to avoid purification. Usual procedure is followed as stated in chlorophylls analysis. The solvent used were $\mathrm{n}$ - butanol : acetic acid : water (60:15:25) and ethanol : water : ammonia sol. (80:10:10) followed by $0.2 \%$ ninhydrin in acetone as locating reagent. The reaction occurs and the coloured spots appeared at the sites of amino acids. A map already prepared using reference $R_{f}$ values of amino acid was used for comparison and identification of separated amino acids on the chromatograms as presented in Table 2.

Preliminary qualitative phytochemical screening of crude extracts was also performed to identify phytoconstituents with respect to amino acids by carrying out Millon's test followed by other physical tests. The chromatographic method reported for the determination of chemical properties and quantification of measure lignans viz phyllanthin (PTN) and hypophyllanthin (HTN) as active ingredients, their $R_{\mathrm{f}}$ values found as 0.21 and 0.24 respectively. The spectral study for their solutions prepared in methanol gave zero-order first derivative response at $259.2 \mathrm{~nm}$ for PTN and $252.4 \mathrm{~nm}$ for HTN.

\subsection{The Analysis of Carbohydrates}

Analysis of carbohydrates as an naturally occurring organic compounds manifested in medicinal plants have been extracted, isolated and examined in n-butanol : acetic acid and water $(4: 1: 5 \mathrm{v} / \mathrm{v})$ chromatographically by determining their $\mathrm{R}_{\mathrm{f}}$ values. In addition to this, the estimation of total alkaloids, terpenoids, glycosides, tannin and ascorbic acid was also reported for the variants of the medicinal plants BA.

\subsection{Serum Glutamic Pyruvic Transaminease (SGPT) Test for Bio-fluid of BA}

The purified sap of the medicinal plant BA-1 under investigation was administered by the patient designated with identification $\mathrm{F}_{3}$, subjected to liver function and SGPT test spectroscopically. The results obtained for various test is shown in Table 3. Similar tests have also been performed for BA-1 and BA-2 medicinal plants respectively. The tests were related to hepatic origin of diseases for elevated serum ALT (SGPT) levels found in hepatitis cirrhosis and obstructive jaundice. Slight elevation of the enzymes is also seen in myocardial infarction ${ }^{\mathbf{1 2}, 13}$. The results of SGPT were observed slightly different for patient when compared with BA-1, BA-2 and BA-3. This is due to different enzyme actions of the hepatitis damage of ALT.

Florescent ${ }^{14-16}$ spectral analysis of the powdered form of system using UV light and various physical parameters of the constituents have also been determined as presented in Table 4. The medicinal plants have genetic control over pH of bio-mass. Enzyme activities are very sensitive to $\mathrm{pH}$ of biofluid 5 to 6 , whenever required during smooth running of vital metabolic activities of the cell during 24 hours in three different seasons. The surface cell density also depends upon the maturity and age of the leaf/phylloclades. 
The electric charge, $\mathrm{pH}$ and molecular weight obstruct, electrophoretic measurement of relative mobility of amino acids in the system. Electrophoretic method reported is suitable for measurement of relative mobility of a few separated amino acids viz alanine, glycine, cystein and threonine as an exemplary with their known and unknown sample of BA-1 at pH 6.6 and 6.7 respectively. It was found that the amino acid with low molecular weight is generally not separated out at low voltage because of diffusion, whereas the amino acids with high molecular weight can easily be separated due to charge and suitable condition of $\mathrm{pH}$ values as recorded in Tables 5 and 6.

\section{CONCLUSION}

The medicinal analysis is very useful in transformation ${ }^{17}$ into pharmacoactive form enhance bioavailability used in generic medicines. The techniques adopted for the determination of chemical profiles of lignans can also be applied for a large number of sample without compromising accuracy.

Table1. Analysis of pigments for medicinal plants Bhumi Amla

\begin{tabular}{|l|l|l|l|l|l|}
\hline \multirow{2}{*}{ S.No. } & \multicolumn{1}{|c|}{ Name of pigment } & \multicolumn{3}{|c|}{ Colour } & \multicolumn{3}{c|}{ Rf value } \\
\cline { 4 - 6 } & & & BA-1 & BA-2 & BA-3 \\
\hline 1. & Chlorophyll-a & Blue green & 0.38 & 0.41 & 0.53 \\
\hline 2. & Chlorophyll-b & Green & 0.23 & 0.35 & 0.44 \\
\hline 3. & Xanthophyll & Yellow brown & 0.50 & 0.59 & 0.56 \\
\hline 4. & Carotene $\alpha$ and $\beta$ & Yellow & 0.86 & 0.89 & 0.93 \\
\hline
\end{tabular}

Table2. Identification of Amino acids from the extract of Bhumi Amla

\begin{tabular}{|c|c|c|c|c|c|c|}
\hline \multirow[t]{2}{*}{ S.No. } & \multirow[t]{2}{*}{ Name of amino acids } & \multirow[t]{2}{*}{ Colour } & \multicolumn{3}{|c|}{ Rf values } & \multirow{2}{*}{$\begin{array}{l}\text { Reference } \\
\mathbf{R}_{\mathrm{f}} \text { value }\end{array}$} \\
\hline & & & BA-1 & BA-2 & BA-3 & \\
\hline 1. & $\begin{array}{l}\text { Alanine } \\
\mathrm{CH}_{3}-\mathrm{CH}-\mathrm{COOH} \\
\left(\mathrm{NH}_{2}\right)\end{array}$ & Deep bluish purple & 0.49 & 0.51 & 0.48 & 0.58 \\
\hline 2. & $\begin{array}{l}\text { Aspartic acid } \\
\mathrm{COOH} . \mathrm{CH}_{2} \cdot \mathrm{CH}\left(\mathrm{NH}_{2}\right) \cdot \mathrm{COOH}\end{array}$ & Light blue & 0.15 & 0.16 & 0.14 & 0.17 \\
\hline 3. & $\begin{array}{l}\text { Cystein } \\
\text { HS-CH} 2-C H-C O O H \\
\quad \mathrm{NH}_{2}\end{array}$ & Grey & 0.59 & 0.65 & 0.70 & 0.72 \\
\hline 4. & $\begin{array}{l}\text { Glutamic acid } \\
\text { COOH.CH} . \mathrm{CH}_{2} \cdot \mathrm{CH} . \mathrm{COOH} \\
\qquad \mathrm{NH}_{2}\end{array}$ & Light orange & 0.19 & 0.18 & 0.25 & 0.26 \\
\hline 5. & $\begin{array}{l}\text { Glycine } \\
\mathrm{NH}_{2} \cdot \mathrm{CH}_{2} \cdot \mathrm{COOH}\end{array}$ & Purple & 0.32 & 0.39 & 0.37 & 0.42 \\
\hline 6. & Histidine $-\mathrm{CH}_{2}-\mathrm{CH}-\mathrm{COOH}$ & Brown & 0.68 & 0.69 & 0.71 & 0.72 \\
\hline 7. & $\begin{array}{l}\text { Leucine } \\
\left(\mathrm{CH}_{3}\right)_{2} \mathrm{CH}-\mathrm{CH}_{2}-\mathrm{CH}\left(\mathrm{NH}_{2}\right)-\mathrm{COOH}\end{array}$ & Light purple & 0.78 & 0.84 & 0.83 & 0.88 \\
\hline 8. & $\begin{array}{l}\text { Lysine } \\
\mathrm{H}_{2} \mathrm{~N}-\left(\mathrm{CH}_{2}\right)_{4}-\mathrm{CH}\left(\mathrm{NH}_{2}\right)-\mathrm{COOH}\end{array}$ & Brown & 0.66 & 0.69 & 0.71 & 0.72 \\
\hline 9. & $\begin{array}{l}\text { Threonine } \\
\mathrm{CH}_{3}-\mathrm{CH}(\mathrm{OH})-\mathrm{CH}\left(\mathrm{NH}_{2}\right)-\mathrm{COOH}\end{array}$ & light Blue & 0.76 & 0.80 & 0.81 & 0.82 \\
\hline 10. & $\begin{array}{l}\text { Valine } \\
\left(\mathrm{CH}_{3}\right)_{2} \mathrm{CH}-\mathrm{CH}\left(\mathrm{NH}_{2}\right)-\mathrm{COOH}\end{array}$ & Blue & 0.74 & 0.77 & 0.75 & 0.78 \\
\hline
\end{tabular}


Table3. Spectral (UV) analysis of bio-mass of sample BA-1, Serum Glutamic Pyruvic Transaminease (SGPT)

Liver Function Test: Id $\mathrm{F}_{3}$

\begin{tabular}{|l|l|l|l|}
\hline S.No. & Types of test & Observed value & Refference value \\
\hline 1. & Total Bilirubin & $0.56 \mathrm{mg} / \mathrm{dl}$ & $0.3-1.1 \mathrm{mg} / \mathrm{dl}$ \\
\hline 2. & Direct Bilirubin & $0.21 \mathrm{mg} / \mathrm{dl}$ & $0.1-0.3 \mathrm{mg} / \mathrm{dl}$ \\
\hline 3. & Indirect Bilirubin & $0.35 \mathrm{mg} / \mathrm{dl}$ & $0.2-0.8 \mathrm{mg} / \mathrm{dl}$ \\
\hline 4. & SGOT & $56 \mathrm{U} / \mathrm{L}$ & $5-37 \mathrm{U} / \mathrm{L}$ \\
\hline 5. & SGPT $($ ALT) & $39 \mathrm{U} / \mathrm{L}$ & $5-42 \mathrm{U} / \mathrm{L}$ \\
\hline 6. & Alkaline Phosphatase & $85 \mathrm{U} / \mathrm{L}$ & $\mathrm{A}:<310 ; \mathrm{C}:<645 \mathrm{U} / \mathrm{L}$ \\
\hline 7. & Total Protein & $6.83 \mathrm{gm} / \mathrm{dl}$ & $6.0-8.5 \mathrm{gm} / \mathrm{dl}$ \\
\hline 8. & Albumin & $4.04 \mathrm{gm} / \mathrm{dl}$ & $3.2-5.5 \mathrm{gm} / \mathrm{dl}$ \\
\hline 9. & Globulin & $2.79 \mathrm{gm} / \mathrm{dl}$ & $2.3-3.5 \mathrm{gm} / \mathrm{dl}$ \\
\hline
\end{tabular}

Table4. Physical parameters of medicinal plants Bhumi Amla

\begin{tabular}{|c|c|c|c|c|c|c|c|}
\hline $\begin{array}{c}\text { S. } \\
\text { No. }\end{array}$ & System & $\begin{array}{c}\text { Weight of } \\
\text { leaf before } \\
\text { treatment }\end{array}$ & $\begin{array}{c}\text { Density } \\
\text { gm/cm }\end{array}$ & $\begin{array}{c}\text { Surface } \\
\text { tension } \\
\text { dynes/cm }\end{array}$ & $\begin{array}{c}\text { Viscosity } \\
\text { (poise) }\end{array}$ & pH value & $\begin{array}{c}\text { Conductivity } \\
\text { Siemen(S) }\end{array}$ \\
\hline 1 & BA-1 & $10.00 \mathrm{gm}$ & 0.751 & 41.70 & 0.0182 & 5.99 & $1.78 \times 10^{-3}$ \\
\hline 2 & BA-2 & $10.00 \mathrm{gm}$ & 0.698 & 42.30 & 0.0175 & 5.67 & $2.23 \times 10^{-3}$ \\
\hline 3 & BA-3 & $10.00 \mathrm{gm}$ & 0.785 & 42.50 & 0.0163 & 5.54 & $1.51 \times 10^{-3}$ \\
\hline
\end{tabular}

Table5. Measurement of relative mobility of known amino acids of Bhumi Amla at pH 6.6

\begin{tabular}{|l|c|c|}
\hline \multirow{2}{*}{ Compound } & \multicolumn{2}{|c|}{ Relative mobility of electrolyte (mm) } \\
\cline { 2 - 3 } & $\mathbf{1}^{\mathbf{a}}$ & -10 \\
\hline Alanine & -10 & - \\
\hline Cysteine & -62 & - \\
\hline Glycine & -117 & -74 \\
\hline Threonine & -73 & $\mathbf{b}^{\mathbf{b}}$ \\
\hline
\end{tabular}

$\boldsymbol{1}^{a}: 2.5 \%(w / v)$ formic acid $78 \%(w / v)$ acetic acid; $p H 6.6,100 \mathrm{v} / \mathrm{cm}$. mobility relative to alanine.

$2^{b}: 2.0 \%(w / v)$ formic acid $20 \%(w / v)$ acetic acid $-0.4 \mathrm{~m} / \mathrm{m}$ cadmium acetate $\mathrm{pH} 6.7,100(\mathrm{v} / \mathrm{cm})$, mobility relative to alanine.

Table6. Relative mobility of few unknown (observed values) Amino acids At 6.7 pH determined by electrophoretic method

\begin{tabular}{|l|c|c|}
\hline \multirow{2}{*}{ compound } & \multicolumn{2}{|c|}{ Relative mobility of electrolyte (mm) } \\
\cline { 2 - 3 } & $\mathbf{1}^{\mathbf{a}}$ & $\mathbf{2}^{\mathbf{b}}$ \\
\hline Alanine & -99 & -99 \\
Cysteine & -57 & - \\
Glycine & -112 & - \\
Threonine & -79 & -77 \\
\hline
\end{tabular}

\section{REFERENCES}

[1] Jain, J.L.: Fundamental of Biochemistry Fourth Edn. S. Chand and company Ltd. New Delhi, 1999.

[2] The wealth of India: Raw material, 1948-1976; Vol 1-11 Revised Edn., 1985; Vol. 1 A.

[3] Giese, Arthur C.: Cell physiology, Fifth Edition, W.B. Saunders Company Toppan Company, LTD Tokyo, Jpan; 1979: 253,239.

[4] Hundet,A., Tripathi,A., Jain, K.M. and Bhatnagar, S.P.: Nat. Acad. Sci. Lett., 1989; 12: 347-349.

[5] Sarabhai, P., Khan, M.U., Nigam,S.K. and Agrawal, R.: J. Chem. France, 2007; 2(C), 06386.

[6] Singh. P.K., Agrawal, R., Khan, M.U., Nigam, S.K. and Khan, Shahnaz.: (Electrochemical kinetic study of calotropis procera), Asian J. Chem., 2007; 19: 213-218

[7] Saket, S.S. and Dwivedi, H.P.: Proc. $47^{\text {th }}$ Annual convention of chemists and International conference on Recent Advances in Chemical Sci. Raipur; 2010.

[8] Swami, M.N., and Nagmani, Manikpurri: (electrochemical kinetic investigation of biosystem), Elect. J. Adv. Res., 2015; 1, No. II: 114-119.

[9] Bunkar, Alka Rani: (Electrochemical study of chemical constituents of Rauwolfia serpentina), Int. J. chemical studies, 2017; 5(1): 9-11. 
[10] Bunkar, Alka Rani: (Therapeutic uses of Rauwolfia serpentina) Int. J. Adv. Sci. and Res., issue, $2017 ; 2$ : 23-26.

[11] Chaturvedi, Jeetnarayan, Sachan. S. and Khan, M.U.: (Electrochemical medicinal analysis of Bhumi Amla), Elect. J. Adv. Res., 2017; Vol. 3 (2): 122-132.

[12] Tietz, N.W.: Fund. of Clinical. Chem., 1970, 447.

[13] Henry, J.B.: Clinical Diagnosis and Management by Laboratory Method W.B. Saunders Co. Philadelphia PA, 1974: 332-335.

[14] Lakowicz, J.R.: Principles of Fluorescence Spectroscopy. Kluwer Academic/ Plenum publishers, 1999.

[15] Vivian, J.T., Callis P.R.: (Mechanisms of tryptophan fluorescence shifts in proteins). Biophys. J., 2001; 80(5).

[16] Gore, M.: Spectrophotometers and spectroflurimetry N.Y. Oxford University Press, 2000.

[17] Bunkar, Alka Rani: (Electrochemical kinetic study of Rauwolfia serpentina xerophytic medicinal plants), Int. J. Chemical studies, 2016; 4(6) : 102-104.

Citation: J. Chaturvedi et al., "Electrochemical Medicinal Analysis of Bhumi Amla", International Journal of Advanced Research in Chemical Science (IJARCS), vol. 5, no. 2, pp. 1-5, 2018. http://dx.doi.org/10.20431/ 2349-0403.0502001

Copyright: (C) 2018 Authors. This is an open-access article distributed under the terms of the Creative Commons Attribution License, which permits unrestricted use, distribution, and reproduction in any medium, provided the original author and source are credited. 